\title{
SUPERVISI BIMBINGAN KONSELING DALAM MENINGKATKAN PENGUASAAN KETERAMPILAN LAYANAN KONSELING GURU BK
}

\author{
Maya Amelisa \\ Universitas Islam Negeri (UIN) Sunan Kalijaga \\ Email:mayamelisa12@gmail.com
}

Suhono

Institut Agama Islam Ma'arif NU (IAIMNU) Metro Lampung

Email: suhono120708@gmail.com

\begin{abstract}
In improving the mastery of Teacher of Counseling and Guidance's services skill requires counseling and guidance supervision. In implementation this supervision, the most common agreement is to make contact section with an supervised client for several time periods. There is a model of the supervision process which is very useful to explain some of these issues that is by analyzing the reflection of the counseling process. Focus of this level is the client by analyzing what is said, how the various parts of the client's life is interlocked, and what the client wants from the oversight of the supervisor's feelings in response. The grabbed information provided a guidance to see the cases which unconsciously can be articulated by supervisors. This library research was performed to explain the best method which can be applied by supervisors in conducting supervision to their clients.
\end{abstract}

Keywords: Supervision of Counselling and Guidance, counseling skills

\begin{abstract}
Abstrak
Dalam rangka meningkatkan penguasaan keterampilan layanan konseling guru BK, maka dibutuhkan supervisi bimbingan konseling. Dalam melaksanakan supervisi ini, hal yang paling umum dilakukan adalah dengan melakukan sesi kontak dengan individu yang dianalisa selama beberapa periode waktu. Terdapat model proses supervisi yang sangat bermanfaat untuk mejelaskan beberapa masalah ini, salah satunya yaitu dengan melakukan analisis refleksi dari muatan sesi konseling yang berlangsung. Fokus dari bimbingan ini adalah klien itu sendiri dengan menganalisa apa yang dikatakan, bagaimana berbagai bagian dari kehidupan klien saling bertautan, serta menganalisa apa yang diinginkan oleh klien. Beberapa informasi yang diberikan oleh klien ini juga dapat memberikan panduan untuk melihat kasus yang secara tidak sadar dapat diartikulasikan oleh pengawas. Tujuan dari dilakukannya penelitian pustakan ini yaitu untuk memberikan pemaparan metode atau cara terbaik yang dapat diaplikasikan oleh para supervisor dalam melakukan supervisi kepada para kliennya.
\end{abstract}

Kata Kunci: Supervisi Bimbingan Konseling, keterampilan konseling

\section{A. PENDAHULUAN}

Dalam menjaga mutu proses pendidikan diperlukan adanya kontrol mutu (quality control) yang mengawasi jalannya proses dan segala komponen 
pendukungnya. Upaya peningkatan sumber daya manusia merupakan upaya yang terintegrasi dengan peningkatan mutu pendidikan. Pendidikan sebagai sektor yang sangat vital dalam rangka membangun sumber daya manusia yang bermutu, memerlukan perhatian yang sangat besar dari semua pihak ${ }^{1}$, khususnya kepala sekolah sebagai guide dalam pelakasanaan pendidikan di sekolah. Fungsi seorang kepala sekolah secara garis besar dikenal dengan istilah Emaslim, yaitu edukator, manajer, administrator, supervisor, leader, inovator, dan motivator. Kepala sekolah sebagai supervisor harus mampu mengoordinasi program-program sekolah, kelompok-kelompok, bahan, dan laporan yang berkaitan dengan sekolah serta para guru atau konselor ${ }^{2}$.

Layanan bimbingan konseling disekolah masih banyak merundung masalah pada tataran praktisnya. Guru Bimbingan Konseling (BK) sebagai konselor disekolah masih mengalami kendala dan masalah yang beragam dan dari beberapa faktor sehingga tak banyak sekolah yang mampu menjalankan layanan BK dengan baik. Sehingga problem ini harus segera disikapi secara positif agar rasa percaya diri guru BK bertambah dalam menjalankan tugasnya, karena dalam hal ini layanan bimbingan dan konseling semangkin tumbuh dan berkembang dan guru BK perlu menyadari bahwa pertumbuhan dan perkembangan profesi merupakan suatu keharusan untuk kinerja dan layanan yang berkualitas.

Kepala sekolah harus mampu berperan sebagai konsultan dalam manajemen sekolah, memberi arah pada pengembangan kurikulum, tenologi pembelajaran atau bimbingan, dan pengembangan staf. Kepala sekolah harus melayani pendidikan dan tenaga kependidikan, baik secara kelompok maupun individual. Ada kalanya, supervisor harus berperan sebagai pemimpin kelompok dalam pertemuanpertemuan yang berkaitan dengan pengembangan kurikulum, pembelajaran atau menejemen sekolah secara umum. Supervisor juga harus melakukan evaluasi terhadap pengelolaan sekolah dan pembelajaran atau bimbingan pada sekolah yang menjadi linggkup tugasnya.

\footnotetext{
1 Syarwani Ahmad et al., “Desain Pembelajaran SMA Plus Negeri 2 Banyuasin III Berbasis Karakter Di Era Masyarakat Ekonomi ASEAN," Iqra': Jurnal Kajian Ilmu Pendidikan 2, no. 2 (2017): h. 403-432.

2Farid mashudi, Panduan Evalusi \& supervisi bimbingan dan konseling , (Jogjakarta: Diva press, 2013), h. 165
} 
Dalam hal ini salah satu faktor yang mempengaruhi meningkat kualitas pada guru yakni supervisi, disini kepala sekolah mempunyai tugas dan tanggung jawab memajukan pengajaran dan menduduki posisi yang sangat strategis didalam upaya pencapaian keberhasilan sekolah, karena disini kepala sekolah bukan hanya sebagai pemimpin tetapi juga sebagai administrator, pendidikan dan supervisor pendidikan yang turut menentukan efektivitas dan efisiensi penyelenggaraan pendidikan disekolah.

Untuk dapat melaksanakan tugasnya tersebut, kepala sekolah tentu harus menguasai berbagai prinsip, metode, dan teknik supervisi, sehingga dapat menentukan strategi, pendekatan, atau model supevisi yang cocok untuk menyelesaikan sutau permasalahan atau program. Materi ini merupakan salah satu bahan yang ditujukan bagi supervisor untuk menguasai kompetesi tersebut.

Layanan konseling bagi profesi Guru Bimbingan Konseling merupakan layanan yang harus dikuasai dengan baik. Karena dalam melakukan layanan membutuhkan beberapa persyaratan. Salah satunya adalah penguasaan keterampilan konseling, tanpa adanya penguasaan keterampilan ini mustahil layana konseling akan dapat berjalan dengan efektif sesuai dengan konsep layanan yang diharapkan, jadi penguasaan keterampilan ini mutlak diperlukan.

Penelitian yang dilakukan oleh Septin Anggraini yang berjudul Peran supervisi BK untuk meningkatkan profesionalisme guru BK memaparkan tentang bagaimana meningkatkan profesionalisme bimbingan dan konseling dibutuhkan pengawasan dan bimbingan dari kepala sekolah sebagai supervisor. Profesionalisme guru BK dan peran supervisi BK dalam meningkatkan profesionalisme guru BK, bertujuan untuk mendiskripsikan profesionalisme guru BK. serta peran supervisi BK dalam meningkatkan profesionalisme guru BK. Tugas kepala sekolah sebagai supervisor telah dilaksanakan oleh kepala sekolah dalam meningkatkan profesionalisme guru BK dengan menggunakan beberapa teknik, diantaranya, percakapan pribadi, diskusi kelompok, penghargaan terhadap guru, penyediaan sumber belajar yang memadai dan pendelegasian guru dalam program edukatif ( MGBK dan Seminar). Belum ada pengawas dari dinas pendidikan yang 
datang secara khusus untuk melakukan supervisi terhadap layanan BK dan belum ada ruangan khusus untuk pelayanan BK. ${ }^{3}$

Selanjutnya penelitian yang dilakukan oleh Carolina L. Radjah, yang berjudul Keterampilan Konseling Berbasis Metakognisi mendeskripsikan karakteristik dan metakognisi konselor Sekolah Menengah Atas. Jenis penelitian yang digunakan deskriptif dengan metode survei. Subyek penelitian adalah konselor sekolah sebanyak 166 orang. Hasil penelitian menunjukkan bahwa dalam proses konseling belum sepenuhnya menerapkan keterampilan konseling berbasis metakognisi. Hal ini mengindikasikan bahwa dalam pelaksanaan konseling, konselor belum mmemperhitungkan keefektifan keterampilan intrapersonal sebagai suatu keterampilan yang terintegrasi dalam diri konselor. ${ }^{4}$

Penelitian ke tiga yang diangkat oleh penulis yaitu penelitian yang dilakukan oleh Muhammad Ilham Bakhtiar yang berjudul Pengembangan video ice breaking sebagai media bimbingan konseling dalam meningkatkan keterampilan sosial membahas penelitian dan pengembangan yang menelaah pengembangan Ice Breaking sebagai media BK untuk meningkatkan keterampilan sosial siswa. Tujuan penelitian adalah (1) Untuk mengembangkan media video ice breaking sebagai media BK yang acceptable (diterima), dalam meningkatkan keterampilan sosial siswa. (2) Untuk mengetahui efektifitas media video ice breaking sebagai media BK dalam meningkatkan keterampilan sosial siswa. Hasil penelitian berupa panduan Ice Breaking dan Video. Hasil penelitian menunjukkan bahwa pengembangan panduan video ice breaking yang acceptabe (diterima), berdasarkan kegunaan (utility), ketepatan (accuracy), kelayakan (faesibility) dan relevansi dalam meningkatkan keterampilan sosial siswa mendapat hasil yang layak untuk di gunakan di SMA Negeri 1 Bontonompo. (2) Panduan video Ice breaking sangat efektif dalam meningkatkan keterampilan sosial siswa di SMA Negeri 1 Bontonompo Kabupaten Gowa. ${ }^{5}$

3Septin Anggraini, "Peran supervisi bk untuk meningkatkan profesionalisme guru Bk," Vol. 1, No. 1, 2017, h. 332-341.

${ }^{4}$ Carolina L. Radjah, "Keterampilan konseling berbasis metakognis,"Jurnal kajian bimbingan dan konseling vol. 1, no. 3, 2016 h.90-94.

${ }^{5}$ Muhammad Ilham Bakhtiar, "Pengembangan video ice breaking sebagai media bimbingan konseling dalam meningkatkan keterampilan sosial," Volume 1 Nomor 2 Desember 2015. h. 150-162 
Adapun berdasarkan penelitian yang dilakukan oleh Kusmaryani, Izzaty, \& Triyanto diketahui bahwa keterampilan konseling masih dapat dikuasai dengan sepenuhnya oleh guru bimbingan konseling meskipun masih terdapat juga guru bimbingan konseling yang belum memahami makna keterampilan konseling. Meskipun keterampilan ini telah dipelajari pada saat mereka menempuh pendidikan sebelumnya, namun seakan-akan keterampilan konseling masing asing dilihat dari dari yang terjadi dilapangan, layanan konseling dilakukan belum sesuai dengan konsep layanan konseling. Selain itu juga belum menggunakan keterampilan secara optimal. ${ }^{6}$

Adapun data yang menunjukan bahwa rata-rata skor tes pemahaman mengenai keterampilan konseling adalah 19,36 atau 52,18\%, skor ini menunjukkan bahwa tingkat pemahaman guru bimbingan konseling masih dalam taraf standar atau sedang. Keterampilan konseling sebagai keterampilan yang vital belum dapat dipahami dengan baik. Padahal sebagian besar guru bimbingan konseling ini berlatar belakang pendidikan bimbingan konseling, dengan latar belakang pendidikan bimbingan konseling yang semestinya pahan dengan keterampilan bimbingan koseling teryata belum sepenuhnya dikuasai dengan baik.

Keterampilan yang sering digunakan dalam layanan konseling adalah keterapilan attending, keterampilan bertanya, keterampilan memberi dukungan dan pengukuhan, keterampilan memdengarkan, keterampilan menutup, keterampilan empati, keterampilan klarifikasi, keterampilan pemecahan masalah, keterampilan pemfokusan, keterampilan memberi dorongan dan keterampilan parafrase. Sementara keterampilan yang jarang atau belum dikuasai seperti keterampilan attaending, keterampilan pemfokusan, keterampilan parafrase, keterampilan konfrontasi, keterampilan membuka diri, keterampilan klarifikasi, keterampilan reframing, dari keterampilan tersebut $47 \%$ subjek melaporkan bahwa

${ }^{6}$ Kusmaryani, R.E., Izzaty, R.E., Sugiyanto., Triyanto, Pengembangan modul keterampilan konseling untuk meningkatkan kinerja guru pembimbing di Yogyakarta, Laporan Penelitian. (Yogyakarta : Lembaga Penelitian,2009). 
keterampilan tersebut telah digunakan secara optimal di lapangan, namun sisanya sebanyak 53\% belum menggunakan keterampilan konseling secara optimal. ${ }^{7}$

Alasan umum yang terjadi adalah adanya keterbatasan kemampuan dan keterampilan konseling, penggunaan keterampilan konseling disesuaikan dengan kebutuhan serta keterbatasan waktu. Alasan-alasan ini menunjukan bahwa penggunaan keterampilan konseling tampaknya masih dianggap banyak memakan waktu. Hal ini karena keterbatasan kemampuan dalam menggunakan keterampilan konseling sehingga guru bimbingan konseling cenderung menggunakan pola lama yang sudah biasa dilakukan, sehingga perkembangan keterampilan konseling terabaikan. Berdasarkan pemaparan diatas adanya asumsi bahwa supervisi bimbingan konseling dilaksanakan sebagai upaya untuk meningkatkan penguasaan keterampilan konseling guru bimbingan dan konseling serta dapatmeningkatkan profesionalisme guru bimbingan konseling.

\section{B. KAJIAN TEORI}

\section{Metode Supervisi}

Terdapat dua metode penelitian dalam supervisi yang dapat dilakukan kepala sekolah. Metode tersebut dibedakan antara yang bersifat individual dan kelompok yang masing-masing mempunyai kelebihan dan kelemahan.

a. Metode supervisi individual; adalah pelaksanaan supervisi yang diberikan kepada konselor tertentu yang mempunyai masalah khusus dan bersifat peronrangan. Supervisor disini hanya berhadapan dengan seorang konselor yang dipandang memiliki persoalan tertentu.

b. Metode supervisi kelompok; adalah satu cara melaksanakan program supervisi yang ditujukan kepada dua orang atau lebih. Konselor-konselor yang diduga, sesuai dengan analisi kebutuhan, memiliki masalah kebutuhan atau kelemahan-kelemahan yang sama dikelompokkan atau dikumpulkan menjadi satu atau bersama-sama. Kemudian kepada mereka diberikan

7Rosita Endang Kusmaryani, Pendidikan dan Latihan (Diklat) Keterampilan Konseling dengan Modul Terstruktur untuk Meningkatkan Kinerja Guru Bimbingan Konseling di Yogyakarta,(Pelaksanaan Kegiatan Program PPM Unggulan, 2010) 
layanan supervisi sesuai dengan permasalahan atau kebutuhan yang mereka hadapi.

\section{Teknik-Teknik Supervisi}

Ada bermacam- macam teknik supervisi dalam upaya pembinaan kemampuan konselor, yang meliputi pertemuan staf, kunjungan supervisi, buletin, profesional, perpustakaan profesional, laboraturium kurikulum, penilaian konselor, demostrasi bimbingan, darmawisata, lokakarya, kunjungan atar kelas, bacaan profesional, survei masyarakat sekolah. Sedangkan, teknikteknik supervisi tersebut bisadikelompokkan menjadi dua kelompok, yaitu teknik supervisi individual dan tenik supervisi kelompok.

Kegiatan supervisi dapat dilakukan melalui berbagai proses pemecahan masalah pengajaran untuk mengubah proses belajar mengajar menjadi kegiatan yang efektif dan efisien. Dalam pelaksanaannya, tentu saja menggunakan teknikteknik supervisi yang merupakan bagian pokok dalam pelaksanaan supervisi pendidikan, maka dari itu teknik dalam melaksanakan supervisi pendidikan diantaranya adalah "teknik perseorangan dan teknik kelompok". Teknik individu, yang meliputi : kunjungan kelas, observasi kelas dan percakapan pribadi dan Teknik kelompok. yang meliputi: orientasi bagi guru-guru baru rapat guru, studi kelompok antar guru, tukar menukar pengalaman, lokakarya, diskusi, seminar. ${ }^{8}$

Piet A. Sahertian dan Ida Alaida Sahertian (1990) mengemukakan tiga cara pendekatan supervisi pengajaran yaitu supervisi yang bersifat directive, collaborative dan non-directive yaitu inspeksi dan supervisi yang bercorak demokratis. Bertolak dari pendapat diatas maka model supervisi bimbingan konseling meliputi Inspeksi ( supervisi yang bersifat directive), non-directive dan collaborative (supervisi yang bersifat demokratis). ${ }^{9}$ 


\section{Kriteria Supervisi Bimbingan Konseling}

Keputusan MENPAN nomor 118 tahun 1996, menetapkan persyaratan umum dan khusus untuk di angkat dalam jabatan pengawas sekolah. Syaratsyarat tersebut berlaku bagi pengawas BK.

a. Syarat umum: Pegawai negeri sipil yang memenuhi angka kriteria yang ditentukan, berkedudukan dan berpengalaman sebagai guru sekurangkurangnya selama enam tahun berturut-turut, telah mengikuti pendidikan dan pelatihan kedinasan dibidang pengawasan sekolah dan memperoleh surat tanda tamat pendidikan, setiap unsur penilaian pelaksanaan pekerjaan sekurang-kurangnya bernilai baik dalam dua tahun terakhir dan sia setinggi-tingginya lima tahun sebelum mencapai batas usia pensiun jabatan pengawas sekolah.

b. Syarat khusus: Pendidikan serendah- rendahnya sarjana atau yang sederajat. berkedudukan serendah-rendahnya guru dewasa, memiliki spesialisasi atau jurusan program bimbingan dan konseling atau bimbingan dan penyuluhan, dan kepala sekolah sebagai Supervisor Pendidikan.

Dalam bidang supervisi kepala sekolah mempunyai tugas dan bertanggung jawab memajukan pengajaran melalui peningkatan profesi guru secara terus menerus. Adapun tugas kepala sekolah tersebut, sebagai berikut: Membantu guru memahami tujuan pendidikan dan apa peran sekolah dalam mencapai tujuan tersebut, membantu guru melihat secara lebih jelas dalam memahami keadaan dan kebutuhan siswanya, membentuk moral kelompok yang kuat dan mempersatukan guru dalam satu tim yang efektif, dan meningkatkan kualitas pengajaran guru baik itu dari strategi, keahlian dan alat pembelajaran. Betapa Pentingnya tujuan pendidikan, Ahmad dkk, menambahkan bahwa Pendidikan pada usia remaja menjadi momen yang penting dalam menentukan karakter seseorang setelah dewasa. Lingkungan 
pergaulan di sekolah maupun di rumah mempunyai peluang yang sama kuatnya dalam pengembangan karakter. ${ }^{10}$

\section{Metode Penelitian}

\section{a. Pendekatan dan Jenis Penelitian}

Jenis penelitian yang digunakan dalam penelitian ini adalah kepustakaan (Library Research) dimana penulis menggunakan pendekatan penelitian normatif deskriptif dengan lebih menekankan pada kekuatan analisis data pada sumber-sumber data yang ada. Maksud dari studi kepustakaan adalah segala usaha yang dilakukan oleh peneliti untuk menghimpun informasi yang relevan dengan topik atau masalah yang akan atau sedang diteliti. Informasi itu dapat diperoleh dari buku-buku ilmiah, laporan penelitian, karangan-karangan ilmiah, tesis, disertasi, peraturan-peraturan, ketetapanketetapan, buku tahunan, ensiklopedia, dan sumber-sumber tertulis lain baik tercetak maupun elektronik.

\section{b. Sumber Data}

Sumber-sumber data dapat dibagi menjadi dua kategori, yaitu sumber data primer dan skunder. Sumber data primer dalam penelitian ini adalah Panduan Evaluasi dan Bimbingan konseling, karya Farid Mashudi. Administrasi dan Supervisi pendidikan, Hartati Sukirman Dkk.. Adapun sumber skundernya adalah segala informasi yang berkaitan dengan tema penelitian ini, baik berupa buku maupun artikel-artikel yang tersebar di berbagai makalah dan web-site.

\section{c. Teknik Pengumpulan Data}

Pengumpulan data dalam penelitian ini dilakukan dengan teknik dokumentasi. Studi dokumen sebagai data tambahan (sekunder), akan tetapi data ini berfungsi memperjelas dan melengkapi data utama. ${ }^{11}$ Studi dokumen

10 Ahmad et al., “Desain Pembelajaran SMA Plus Negeri 2 Banyuasin III Berbasis Karakter Di Era Masyarakat Ekonomi ASEAN."

11 Ahmad et al. 
dilakukan dengan penelitian mengenai dokumen-dokumen yang berkaitan dengan teori supervisi bimbingan konseling. Teknik ini digunakan untuk melacak dokumen, data dan informasi baik yang berupa buku, majalah, jurnal ilmiah, artikel, dan lain sebagainya yang relevan dengan penelitian ini.

\section{d. Metode Analisis}

Untuk menganalisa data, penulis menggunakan content analysis (analisis isi) sebagaimana dikutip oleh Burhan Bungin (2003:173) mengatakan bahwa content analysis adalah suatu metodologi penelitian yang memanfaatkan seperangkat prosedur untuk menarik kesimpulan yang sahih dari sebuah buku atau dokumen.

\section{PEMBAHASAN}

Guru bimbingan konseling dalam Undang-Undang No 20 Tahun 2003 Pasal 1 Ayat 6 keberadaan konselor atau guru BK dalam Sistem Pendidikan Nasional dinyatakan sebagai salah satu kualifikasi pendidik, sejajar dengan kualifikasi guru, dosen, pamong belajar, tutor, widyaiswara, fasilitator dan instruktur. Dalam surat keputusan Bersama Mendikbud dan kepala BAKN No. 0433/P/1993 dan No. 25 Tahun 1993 tentang Petunjuk Pelaksanaan Jabatan Fungsional Guru Pembimbing dan Angka Kreditnya dijelaskan bahwa "guru pembimbing adalah guru yang mempunyai tugas, tanggung jawab dan wewenang. ${ }^{12}$

Dalam hal ini konseling adalah upaya bantuan yang diberikan oleh seorang guru bimbingan konseling yang terlatih dan berpengalaman, terhadap individu yang mempuyai problem. Membimbing dan mendidik keberadaannya merupakan bagian yang integra dalam proses pendidikan dengan tujuan untuk membekali anak dalam memecahkan segala masalah-masalah kehidupan yang diahadapinya. ${ }^{13}$ Hal ini bertujuan untuk mengembangkan potensi diri individu secara optimal, dan mampu menyesuaikan diri terhadap lingkungan. Konseling menekankan ide

12Undang-Undang Republik Indonesia No. 20 Tahun 2003 tentang Sistem Pendidikan Nasional, (Bandung: Fokusmedia. 2003).

13 Heri Cahyono, Suhono Suhono, dan Aisyah Khumairo, "Pendidikan Karakter Bagi Pelaku Pedofilia (Sebuah Strategi Dalam Mengatasi Amoral)," JMKSP (Jurnal Manajemen, Kepemimpinan, dan Supervisi Pendidikan) 3, no. 1 (2017). 
hubungan profesional, pentingnya pengembangan potensi diri dan penyesuaian diri agar mampu mengatasi masalah. Dalam pengaplikasian konseling sangat diperlukan penguasaan keterampilan dan pengembangan kepribadian.

Keterampilan dalam konseling memiliki fungsi untuk merefleksikan informasi dan sikap yang dimiliki oleh konseli, dari kajian literatur (Willis, 2007) ${ }^{14}$ disimpulkanbahwa keterampilan konseling mencakup keterampilan attending, mendengarkan, empati, bertanya, pemusatan, klarifikasi, membuka diri, memberi dukungan dan pengukuhan, memberi dorongan, pemecahan masalah, dan menutup percakapan. Berkenaan dengan keterampilan konseling, bedasarkan hasil penelitian tahun 2009, Rumusan standar kompetensi konselor telah dikembangkan dan dirumuskan atas dasar kerangka pikir yang menegaskan konteks tugas dan ekspetasi kinerja konselor.

\section{Supevisi Bimbingan Dan Konseling}

Supervisi diadopsi dari bahasa inggris yakni "supervision" yang berarti pengawasan dan kepengawasan. Sementara itu beberapa ahli seperti yang dikutip oleh Piet A. Sahertian memberikan rumusan yang berbeda-beda antara lain: a) merumuskan supervisi sebagai program yang berencana untuk memperbaiki pengajaran (perbaikan hal belajar mengaja. ${ }^{15}$ Dari pengertian diatas maka dapat disimpulkan bahwa supervisi adalah segenap usaha menstimulasi, mengkoordinasi dan membimbing secara continue pertumbuhan guru.

Supervisi bimbingan konseling adalah upaya untuk mendorong, mengkoordinasikan dan menuntun pertumbuhan petugas bimbingan konseling atau konselor secara berkesinambungan baik secara individual maupun kelompok agar lebih memahami dan lebih dapat bertindak secara efektif dalam melaksanakan layanan bimbingan konseling, sehingga mereka mampu mendorong pertumbuhan tiap siswa (klien) secara berkesinambungan

14Willis, S. Konseling Individual; Teori dan Praktik.( Bandung : Penerbit Alfabeta:(2007)

${ }^{15}$ Ibid 
agar dapat berpartisipasi secara cerdas dan kaya di dalam kehidupan masyarakat demokratis.

Pihak yang berwenang dalam melakukan supervisi ini adalah kepala sekolah maka dari itu kepala sekolah tentu harus menguasai berbagai prinsip, metode, dan teknik supervisi, sehingga dapat menentukan strategi, pendekatan, atau model supevisi yang cocok untuk menyelesaikan suatu permasalahan atau program. Materi ini merupakan salah satu bahan yang ditujukan bagi supervisor untuk menguasai kompetesi tersebut.

\section{Kompetensi Kepala Sekolah}

Ada lima kompetensi atau keahlian yang harus dimiliki oleh seorang kepala sekolah. Kelima kompetensi itu meliputi kompetensi kepribadian, manajerial, sosial, kewirausahaan, dan supervisi. Kompetensi supervisi adalah kemampuan kepala sekolah dalam pelaksanaanya, yakni menilai dan membina guru atau konselor dalam rangka mempertinggi kualitas proses pembelajaran yang dilaksanakannya, agar berdampak terhadap kualitas hasil belajar klien.

Inti dari supervisi adalah membina guru atau konselor dalam meningkatakan mutu pembelajaran. Oleh itu, tujuan umum supervisi disekolah, serta mengembangkan mengembangkan kemampuan dalam menilai dan membina guru untuk mempertinggi kualitas proses pembelajaran yang dilaksanakannya agar berdampak terhadap kualitas hasil belajar klien. ${ }^{16}$

Rumusan Supervisi Seorang Kepala Sekolah, (Farid Mashudi, 2013):

1) Mampu melakukan supervisi sesuai kebutuhan guru

a. Mampu melakukan supervsi bagi konselor/guru dengan menggunakan ternik supervisi yang tepat.

b. Mampu menindaklanjuti hasil supervisi kepada guru/ konselor melalui pengembangan profesional guru, penelitian tindakan kelas, dan sebagainya.

${ }^{16}$ Farid mashudi, Panduan Evalusi \& supervisi bimbingan dan konseling , (Jogjakarta: Diva press, 2013), h. 167 
2) Mampu melakukan monitoring, evaluasi, dan pelaporan program pendidikan sesuai dengan prosedur yang tepat:

a. Mampu menyusun standar kinerja program pendidikan yang dapat diukur dan dinilai.

b. Mampu melakukan monitoring dan evaluasi kinerja program pendidikan dengan menggunakan teknikyang sesuai.

c. Mampu menyusun laporan sesuai dengan standar pelaporan monitoring dan evaluasi.

\section{Pendekatan dalam Supervisi}

Menurut sahertian (sahertian, 2000:44-52), ada tiga pendekatan yang digunakan dalam melaksanakan supervisi yaitu: ${ }^{17}$

a. Pendekatan langsung

Pendekatan langsung adalah cara pendekatanvterhadap masalah yang bersifat langsung. Karena supervisor mamberi arahan langsung, sudah tentu pengaruh perilaku supervisor lebih dominan.

b. Pendekatan tidak langsung (nondirektif)

Pendekatan nondirektif adalah pendekatan terhadap permasalah yang bersifat tidak langsung. Perilaku supervisor tidak secara langsung menunjukkan permasalahan, tetapi ia terlebih dahulu mendengarkan secara aktif apa yang dikemukakan para konselor.

c. Pendekatan kolaboratif

Yang dimaksud dengan pendekatan kolaboratif adalah pendekatan yang memadukan cara pendekatan direktif dan nondirektif menjadi pendektan baru. Pada pendekatan ini, baik supervisor maupun konselor, bersepakat menetapkan struktur, proses, dan kriteria dalam melaksanakan proses percakapan terhadap masalah yang dihadapi konselor. Dengan demikian pendekatan dalam supervisi berhunbungan pada dua arah, dari atas dan 
dari bawah kea ata. Perilaku supervisor adalah menyajikam, menjelaskan, memdengarkan, memecahkan masalah, dan negosiasi.

Fungsi dari supervisi BK adalah meonitor, mencatat, memberi dukungan, megukur, dan manilai kinerja, dan mendorong untuk merefleksikan

Supervisi berarti pengawasan, penilikan, dan pembinaan. Secara terminolog, supervisi adalah bantuan berbentuk pembinaan yang diberikan kapada seluruh staff sekolah untuk mengembangkan situasi belajar-mengajar yang lebih baik. Setelah mengetahui supervisi, harus diketahui juga pengertian dari bimbingan, baik secara umum maupun khusus.

Bimbingan bersifat umum merupakan usaha-usaha untuk memberikan penerangan atau pendidikan agar yang menerima bimbingan lebih mengetahui , lebih menyenangi dan bersikap positif. Bimbingan yang bersifat khusus adalah bimbingan yang diberikan guru, pembimbing, atau konselor, kepada anak yang dalam perkembangan pendidikannya memperlihatkan kelambatan atau hambatan.

Adapun program kegiatan supervisee bukan merupakan konseling/psikoterapi, pemaksaan (imposing), kritik negatif (negative criticism), memperdayakan (disempowering), pertemanan (friendship), mencari kesalahan (fault finding), hukuman (punishment), maupun untuk konselor yang baru (vovicecounselor).

Tujuan yang diharapkan tercapai dalam supervisi BK di sekoalah, yaitu meningkatkan kesadaran dan identitas profesional, mendorong perkembangan pribadi dan profesional, mempromosikan kinerja profesional, dan memberikan jaminan mutu terhadap praktik profesional. Namun demikian, dalam pelaksanaan supervisi BK perlu diperhatikan beberapa prinsip dasarsupervisi $\mathrm{BK}$, sehingga proses yang dilakukan bisa terukur dan dipertanggungjawabkan. Secara garis besar prinsip supervisi BK ada dua, yaitu:

1. Prinsip umum

Supervisi harus bersifat praktis, dalam arti dapat dikerjakan sesuai dengan situasi dan kondisi sekolah: 
a. Hasil supervisi harus berfungsi sebagai sumber-sumber informasi bagi staf sekolah untuk mengembangkan proses belajar mengajar bimbingan konseling;

b. Supervisi dilaksanakan dengan mekanisme yang menunjang kurikulum yang berlaku.

2. Prinsip khusus

Supervisi hendaknya dilaksanakan secara sistematis, objektif, realistis, antisipatif, konstruktif, dan kreatif.

a. Sistematis artinya supervisi dikembangkan dengan perencanaan yang matang sesuai dengan sasaran yang diingiinkan;

b. Objektif artinya supervisi memberiakan masukan sesuai dengan aspek yang terdapat dalam instrumen;

c. Realistis artinya supervisi didasarkan atas kenyataan yang sebenarnya, yaitu pada keadaan hal-hal yang sudah dipahami dan dilakukan oleh para staf sekolah;

d. Antisipatif artinya supervisi diarahkan untuk menghadapi kesulitan yang mungkin akan terjadi;

e. Konstruktif artinya supervisi memberikan saran perbaikan kepada yang disupervisikan untuk berkembang sesuai dengan ketentuan atau aturan yang berlaku;

f. Kreatif artinya supervisi mengembangkan.

Adapun tujuan dari Supervisi bimbingan dan konseling diantaranya: Tujuan mengendalikan kualitas, supervisor bertanggung jawab memonitor pelaksanaan kegiatan bimbingan konseling dan hasil-hasilnya yang berupa kehidupan dan perkembangan siswa atau klien yang lebih baik. maka supervisor bimbingan konseling perlu memiliki Kemampuan dalam kepemimpinan, kemampuan dalam hubungan manusia, kemampuan dalam proses kelompok kemampuan dalam administrasi personel, kemampuan dalam bimbingan konseling dan kemampuan dalam evaluasi. ${ }^{18}$ 
Berdasarkan hasil dari pembahasan yang sudah dijelaskan di atas, maka dapat ditarik kesimpulan. Bahwa supervisi bimbingan konseling terbukti efektif dapat meningkatkan keterampilan, pemahaman guru bimbingan konseling dan mampu dalam meningkatkan penguasaan praktek konseling. Dimana dengan diterapkannya supervisi bimbingan konseling yang dilakukan kepala sekolah dapat membantu guru bimbingan konseling untuk meningkatkan dan lebing mengembangkan skill dalam keterampilan layanan bimbingan konseling.

format berbeda dalam pelaksanaan supervisi. Kesepakatan paling umum adalah membuat kontrak sesi individual selama beberapa periode waktu dengan orang yang sama. Ada model proses supervisi yang sangat bermanfaat untuk mejelaskan beberapa isu ini; terdapat enam level operasi dalam supervisi. Pertama, reflesi terhadap muatan sesi konseling. Fokus dari level ini adalah klien; apa yang diucapkan, bagaimana berbagai bagian dari kehidupan klien saling bertautan, dan apa yang diinginkan klien dari penyuluhan.

Kedua, eksplorasi teknik dan strategi yang digunakan oleh konselor. Lebih jauh, Yeasy dan Suhono menjelaskan bahwasanya Strategy is a plan to reach the goal through learning process. ${ }^{19}$ Level ini berkenaan dengan maksud terapeutik konselor dan pendekatan yang diambilnya untuk membantu klien. Ketiga, eksplorasi terapeutik. Tujuan dari level ini adalah menguji cara interaksi antara klien dan konselor, serta apakah mereka telah membangun aliansi kerja yang berfungsi.

Keempat, perasaan konselor kepada klien. Tujuan dari level supervisi ini adalah mengindentifikasi dan memahami reaksi conter-transference konselor dan isu personal yang dirangsang kembali melalui kontak dengan klien. Kelima, sesuatu yang terjadi saat ini dan sekarang antara supervisor dan yang diawasi. Hubungan yang terjadi dalam sesi supervisi mungkin memaparkan karakteristik yang mirip dengan hubungan antara konselor hubungan antara konselor dan kliennya. 
Keenam, perasaan pengawas dalam merespons dari klien yang diawasi juga dapat memberikan panduan beberapa cara untuk melihat kasus yang tidak secara sadar diartikulasikan oleh pengawas atau yang diawasi, sekaligus memberikan konstribusi terhadap pemahaman kualitas hubungan pengawas dengan yang diawasi.

Sementara itu dampak supervisi konseling yang tidak efektif adalah sebagai berikut:

1. Tidak ada balikan dari orang yang kompeten; apakah praktik profesional telah memenuhi standar kompetensi dan kode etik;

2. Ketinggalan IPTEK dalam BK;

3. Kehilangan identitas profesi BK;

4. Kejenuhan profesioanal (bornout);

5. Pelanggaran kode etik yang akut;

6. Mengulang kekeliruan secara masif;

7. Erosi pengetahuan yang sudah didapat dari pendidikan prajabatan; dan

8. Siswa dirugikan, tidakk mendapatkan layanan BK sebagaimana mestinya.

Dari fakta lapangan belum pernah ada pengawas dari dinas pendidikan yang datang secara khusus untuk melakukan supervisi terhadap layanan bimbingan konseling dan belum adanya ruangan khusus untuk bimbingan konseling. Sehingga menjadikan keterampilan guru bimbingan konseling masih monoton atau ketinggalan dengan berkembangnya keterampilan konseling yang lebih efektif dalam menyelesaikan suatu masalah. Jadi disini guru bimbingan konseling disarankan untuk lebih aktif dan memberikan variasi dalam melaksanakan layanan bimbingan dan konseling, sehingga siswa merasa diperhatikan dan tertarik dengan layanan bimbingan dan konseling.

\section{E. KESIMPULAN}

Dalam bidang supervisi bimbingan konseling, kepala sekolah mempunyai tugas dan bertanggung jawab memajukan pengajaran melalui peningkatan profesi 
guru secara terus menerus. Adapun tugas kepala sekolah tersebut, sebagai berikut: (1) Membantu guru memahami tujuan pendidikan dan apa peran sekolah dalam mencapai tujuan tersebut; (2) membantu guru melihat secara lebih jelas dalam memahami keadaan dan kebutuhan siswanya; (3) membentuk moral kelompok yang kuat dan mempersatukan guru dalam satu tim yang efektif; (4) serta meningkatkan kualitas pengajaran guru baik itu dari strategi, keahlian dan alat pembelajaran.

Berdasarkan kesimpulan diatas maka hendaknya guru BK mulai responsif dengan perkembangan keterampilan teknik konseling yang ada sekarang dan hendaknya keterampilan konseling ini sering diimplementasikan, sehingga tepat sasaran dalam melakukan penanganan. Selanjutnya diharapkan hal ini akan membantu pelaksanaan proses konseling yang lebih efektif. Selanjutnya diharapkan kepada supervisor bimbingan konseling ini agar dapat melaksanakan tugasnya dengan baik di sekolah sehingga hal itu dapat membantu para guru BK untuk dapat lebih terampil dalam penguasaan teknik bimbingan konseling.

\section{DAFTAR PUSTAKA}

Ahmad, S., Kristiawan, M., Tobari, T., \& Suhono, S. (2017). Desain Pembelajaran SMA Plus Negeri 2 Banyuasin III Berbasis Karakter Di Era Masyarakat Ekonomi ASEAN. Iqra': Jurnal Kajian Ilmu Pendidikan, 2(2), 403-432.

Cahyono, Heri, Suhono Suhono, dan Aisyah Khumairo. "Pendidikan Karakter Bagi Pelaku Pedofilia (Sebuah Strategi Dalam Mengatasi Amoral)." JMKSP (Jurnal Manajemen, Kepemimpinan, dan Supervisi Pendidikan) 3, no. 1 (2017).

Carolina L. Radjah, Keterampilan konseling berbasis metakognis,Jurnal kajian bimbingan dan konseling,http://journal.um.ac.id/index.php/bk vol. 1, no. 3, 2016

Farid mashudi. (2013) Panduan evaluasi dan bimbingan konseling, yogyakarta:Diva press

Hartati Sukirman Dkk, Administrasi dan Supervisi Pendidikan, Yogyakarta : Fakultas Ilmu Pendidikan UNY, 2007.

Kusmaryani, R.E., Izzaty, R.E., Sugiyanto., Triyanto, A. (2009). Pengembangan modul keterampilan konseling untuk meningkatkan kinerja guru pembimbing di Yogyakarta. Laporan Penelitian. Yogyakarta : Lembaga Penelitian

Mcleod, J. (2007). Counselling skill. Berkshire: Mc Graw Hill Education 
Muhammad Ilham Bakhtiar, Pengembangan video ice breaking sebagai media bimbingan konseling dalam meningkatkan keterampilan sosial, http:/ /ojs.unm.ac.id/index.php/JPPK Volume 1 Nomor 2 Desember 2015

Septin Anggraini, Peran supervisi bk untuk meningkatkan profesionalisme guru Bk,http://pasca.um.ac.id/conferences/index.php/snbk,Vol. 1, No. 1, 2017.

Sari, Y. A., \& Suhono, S. (2017). Applaying Transition Action Detail Strategy on Written Text of EFL Young Learners. Iqra': Jurnal Kajian Ilmu Pendidikan, 2(1), 1-24.

Suwardji Lazaruth, Tugas dan Tanggung Jawab Kepala Sekolah, Yogyakarta: Kanisius, 1996.

Tan, E. (2004) Counseling in school: Theories, processes and techniques. Singapore: McGraw-Hill Education (Asia).

Undang-Undang Republik Indonesia No. 20 Tahun 2003 tentang Sistem Pendidikan Nasional, Bandung: Fokusmedia. 2003.

Undang-Undang Republik Indonesia No.14 tahun 2005 TENTANG Guru Dan Dosen, http://kepri.kemenag.go.id/file/file/Un Dan Undang/lysc1391498449.PDF, diakses pada 11 Maret 2017.

W.S. Winkel dan M.M Sri Hastuti, Bimbingan dan Konseling, Yogyakarta: Media Abadi, 2010.

W.S. Winkel, Bimbingan dan Konseling di Institusi Pendidikan, Jakarta : PT. Gramedia Mediasarana, 1997.

Willis, S. (2007). Konseling Individual; Teori dan Praktik. Bandung : Penerbit Alfabeta.

Tan, E. (2004) Counseling in school: Theories, processes and techniques. Singapore: McGraw-Hill Education (Asia).

Willis, S. (2007). Konseling Individual; Teori dan Praktik. Bandung : Penerbit Alfabeta.

Ahmad, Syarwani, Muhammad Kristiawan, Tobari Tobari, dan Suhono Suhono.

“Desain Pembelajaran SMA Plus Negeri 2 Banyuasin III Berbasis Karakter Di

Era Masyarakat Ekonomi ASEAN." Iqra': Jurnal Kajian Ilmu Pendidikan 2, no. 2 (2017): 403-432.

Cahyono, Heri, Suhono Suhono, dan Aisyah Khumairo. "Pendidikan Karakter Bagi Pelaku Pedofilia (Sebuah Strategi Dalam Mengatasi Amoral)." JMKSP (Jurnal Manajemen, Kepemimpinan, dan Supervisi Pendidikan) 3, no. 1 (2017).

Sari, Yeasy Agustina, dan Suhono Suhono. "Applaying Transition Action Detail Strategy on Written Text of EFL Young Learners." Iqra': Jurnal Kajian Ilmu Pendidikan 2, no. 1 (2017): 1-24. 